\title{
16 Democracy promotion and the New Public Diplomacy
}

\author{
Giles Scott-Smith and Martijn Mos
}

\section{Introduction}

In the wake of $9 / 11$, the United States government set out to clarify the values it stood for in the world. The second section of the 2002 National Security Strategy of the United States, which outlined the aim to 'Champion Aspirations for Human Dignity,' spelled out a series of 'nonnegotiable demands': the rule of law, free speech, freedom of worship, equal justice, and respect for private property. The intention was to direct US actions and resources towards 'expanding liberty' and 'the development of democratic institutions' around the world. This chapter will focus on US public diplomacy efforts to realize this agenda.

Public diplomacy covers an array of government-sponsored activities that aim to influence opinion abroad, thereby creating a more positive, supportive environment within which foreign policies can be conducted. It therefore covers everything from government information programs and news broadcasting to the active role of the private sector in running exchange programs and in cultural diplomacy projects covering the arts. From 1953 to 1999 the main body responsible for this was the United States Information Agency (USIA), which conducted and coordinated its activities with the State Department (Dizard 2004). In 1999, the Foreign Affairs Restructuring Act dissolved USIA and transferred its information and exchange activities to the State Department, whereas broadcasting was placed under the supervision of the independent Broadcasting Board of Governors.

The need to respond rapidly to the shock of $9 / 11$ exposed the fact that public diplomacy had been seriously neglected during the 1990s. As the independent Public Diplomacy Council stated in 2005:

Buffeted by a decade of budget cuts, hampered by bureaucratic structures that marginalize it and call on its expertise too late in the policy process, public diplomacy as currently constituted is inadequate to perform the urgent national security tasks required of it - to inform, to understand and to influence world publics.

(Public Diplomacy Council 2005: 3)

The emphasis here will be placed on the tensions that have appeared throughout the pursuit of public diplomacy by the United States since 2001. Following the horror of 9/11 there was widespread empathy around the world which could have formed the basis for a US-led international effort to solve problems in a host of policy areas. Instead, concerns over the negative image of the United States abroad and the startling 
results of opinion polls conducted by the Pew Research Center (particularly in the Middle East) caused an emphasis to be laid on improving the way others understood US values, goals, and actions. This one-way approach sought to deal with the question 'why do they hate us?' not via an engagement with others' concerns, but with an intensified portrayal of why the United States continued to offer the best example to the rest of the world. The declaration of a War on Terror also had major implications, since it not only demanded that all information activities be placed under a national security imperative, but it also increased the role of the Pentagon in media management. The result has been an intensification of efforts to control the message, instead of reflecting on what the message should be and why it was being received by others in certain ways. As a result, the democratizing potential of public diplomacy initiatives, which ideally work towards empowerment and merging interests with others as much as projecting the merits of a defined national interest to others, has largely been submerged under more limited national security objectives.

\section{The New Public Diplomacy}

Public diplomacy was first referred to as a recognizable field of activity in 1965 by Edmund Gullion, a former US Ambassador to the Congo who used the opportunity of opening the Edward R. Murrow Center at Tuft University's Fletcher School of Law and Diplomacy to outline that it entailed:

the influence of public attitudes on the formation and execution of foreign policies. It encompasses dimensions of international relations beyond traditional diplomacy ... [including] the cultivation by governments of public opinion in other countries; the interaction of private groups and interests in one country with those of another ... (and) the transnational flow of information and ideas. ${ }^{1}$

Up to this point, public diplomacy activities had been referred to either as politicallyneutral cultural relations and educational exchange, or as propaganda, which early studies of USIA admitted was essentially the purpose (Dizard 1961). Gullion's definition, on the other hand, highlighted certain aspects that mark out public diplomacy as a unique area of activity. First, the emphasis on the domestic impact of public opinion on the crafting of foreign policy. Second, the essential role of the private sector in building transnational connections, either in collusion with or independent of government. However, the claim that this was 'beyond traditional diplomacy' situated public diplomacy as an addendum to existing channels of inter-state relations. It also assumed, despite its recognition of the role of the private sector, that the nation-state could still make use of public diplomacy as a unitary actor pursuing the national interest abroad.

In recent years there has been increasing interest in the importance of public diplomacy. There are two main strands to this. First, there has been a focus on 'strategic public diplomacy,' a field that draws on political communication and 'the creation, distribution, control, use, processing, and effects of information as a political resource.' Messages are crafted and targeted according to the behavior patterns, cultural norms, and media consumption of a specific audience (Manheim 1994: 7-9). Second, and more extensive in its implications, there is what has become known as New Public Diplomacy, which seeks not just to secure a favorable reception for foreign policies 
abroad, but also to reflect on how the entire diplomatic machinery of nation-states needs to be overhauled in line with the demands of a changing global political environment. These changes can be outlined in terms of the structure and process of global politics. In terms of structure, the position of the nation-state as an actor within the international system has come under question (Guehenno 2000). Regarded as the preeminent unit in international politics since the Treaty of Westphalia in 1648, it is now operating alongside transnational corporations (TNCs) and non-governmental organizations (NGOs) which, if not partners of an equal stature, are nevertheless increasingly relevant (if not unavoidable) for the successful formulation and implementation of foreign policy. What is more, the level of integration in certain policy fields coupled with the development of supranational organizations has further altered the space within which nation-states operate (Hocking 1999; Melissen 1999; Riordan 2003). As a result foreign policy will 'no longer be the sole province of governments' (Nye 2002: 60).

In terms of processes, the post-Cold War era has witnessed a remarkable shift in the ways that foreign policy and diplomatic activity are now viewed. First, the diversification of media outlets and the diffusion of information and communication technologies have increased the availability of information (to those online and hooked up, at least) and lessened the ability of nation-states to control the news agenda. Other actors, right down to individual citizens, are now able to contribute to and even seize the ways in which news is presented to a global audience. Second, and connected to this, there has been an increasing transparency to political activity in line with the general wave of democratization that occurred following the break-up of the Soviet Union and the end of the Cold War. The decline of foreign policy as the domain of an elite establishment, coupled with the need to legitimize policies in the eyes of the domestic public, has altered the relationship between government and citizen. In this context, strategic public diplomacy aims to carve out a unique place for government communications within the increasingly crowded airwaves. The New Public Diplomacy, on the other hand, aims not so much to take the domestic constituency into account, but also to seek out ways in which it can be utilized to further specific interests of the nation-state as a whole (Brown 2004: 14-19; Hocking 2005: 28-41; Melissen 2005: 3-27). After all, the private sector generally possesses a greater credibility abroad, and through this manages to acquire greater access to regions or constituencies otherwise out of reach of official contact (Leonard 2002).

Strategic public diplomacy is basically an extension of the propaganda and psychological warfare techniques developed during World War II, now applied by governments in peaceful situations. New Public Diplomacy, on the other hand, contrasts with former approaches in three ways: (1) the importance of non-state actors alongside and outside of inter-state relations has increased; (2) the practice of public diplomacy abroad is intimately and necessarily linked to the practice of public affairs at home; and (3) it is not so much geared towards the management of information for the purpose of convincing others to adopt another point of view, but towards an engagement with other constituencies with the aim of establishing a dialogue on the grounds of mutual interest or concern (Melissen 2005: 12-13). The hierarchies of Westphalian state-centric relations are breaking down, and new opportunities - and challenges - are taking their place. The New Public Diplomacy is therefore not so much an addendum to diplomatic practice as the basis for its actual reformulation in the twenty-first century.

The conduct of US public diplomacy following $9 / 11$ has reflected both 'strategic' and 'new' dimensions. Determined to reinstate the primacy and power of democratic values, 
the emphasis was placed on getting the message out more consistently and at a louder volume. The Defense Department in particular has expanded its public diplomacy activities in a search for greater 'strategic influence' (Gough 2003). The State Department, ostensibly responsible for the public diplomacy effort, has oscillated between talking the new language but operating according to narrow national security demands. Whereas there was a need for a long-term strategy of engagement, instead the public diplomacy that emerged was 'reactive and not the product of forward-looking foreign services caring about relationships with foreign audiences as a new challenge in diplomatic practice' (Melissen 2005: 9). In 2005, the Congressional Research Service conducted a survey of 29 articles and studies on US public diplomacy conducted since 2001 in an attempt to highlight where most of the criticisms lay. The results indicated that most concerns centered on the lack of strategic direction, with the State Department unable make public diplomacy a priority and the White House failing to coordinate between different departments and agencies of government. Further, there was consistent support for an increase in financial investment in human resources, language training, and the forms of public diplomacy that encourage greater dialogue such as exchange programs, information centers, and libraries (CRS 2005). Funding for educational and cultural exchange programs had stagnated through the 1990s, being \$242 million in 1993 and still only \$245 million in 2003, effectively a decline in real terms (US Advisory Commission 2004: 18). The Council on Foreign Relations published two reports which emphasized the need to move away from a focus on one-way mass communications and invest in methods of engagement that involved fostering debate, dialogue, and taking into account the views of others (Council on Foreign Relations 2002, 2003). Above all, there was general agreement that it had been a mistake to close down USIA, as the result was a fragmented and uncoordinated public diplomacy infrastructure distributed across various locations in the government (Zwiebel 2006).

\section{The State Department: the Under Secretary of State for Public Diplomacy and Public Affairs}

The position of Under Secretary was created following the demise of USIA, and on paper seemed to offer the chance to coordinate domestic outreach (public affairs) with public diplomacy abroad, in line with the assumptions of the New Public Diplomacy. The Under Secretary is responsible for three bureaux: Educational and Cultural Affairs, International Information Programs, and Public Affairs. They are assisted in their task by the US Advisory Commission on Public Diplomacy, a bipartisan panel appointed by the President which can make recommendations for improvements.

The first person to hold the post of Under Secretary was Evelyn Lieberman, formerly the Deputy Chief of Staff in the White House and, during 2008, chief operating officer on Hilary Clinton's presidential campaign. Lieberman served during the last phase of the second Clinton administration, and the position only took on real significance after 9/11. Charlotte Beers was sworn in on 2 October 2001, and as a top advertising executive with J. Walter Thompson, Tatham-Lair \& Kudner, and Ogilvy \& Mather, Beers had a reputation for marketing well-known brands such as Uncle Ben's Rice. With 9/11 raising serious questions about the ways in which the United States was perceived by others, it became Beers' responsibility to improve attitudes towards the United States abroad, with special emphasis on the Middle East. As she stated to the House Foreign Relations Committee a week after being sworn in, she was determined 
'to wholeheartedly focus on our number-one priority: fighting the international war on terrorism.' ${ }^{2}$

There were four basic elements that Beers concentrated on: The Messenger, Magnification, Authenticity, and Context. ${ }^{3}$ The emphasis on messengers entailed only that all government spokespersons needed to be credible in approach and outlook. Magnification was a term Beers brought from the world of advertising, and in the field of US public diplomacy it referred first to the ability to spread the message in as many languages as possible, and second to the role of each US embassy to expand its formal and informal contacts with local communities. It also involved engaging with media channels which up to that point had been ignored or regarded as hostile to US interests, such as Abu Dhabi TV and Al Jazeera. Third-party authenticity covered the aim to obtain public support for US foreign policies from independent advocates, thereby raising the level of legitimacy for those policies in the eyes of others. As Beers stated, 'There is no question that we are in a time where we desperately need to have other voices speaking for us, and not literally for us, but in their own voice and in their own way.' This was a standard approach from Cold War information campaigns, but Beers' reference to third-party authenticity as 'TV Co-Ops' indicated that its application after 9/11 represented purely a short-term effort to secure as much media exposure as possible. ${ }^{4}$ The last factor in Beers' vision of public diplomacy was context, by which she meant providing the facts and conveying emotions, including the need for 'storytelling,' by which she meant highlighting the human element to events in a way that could alter others' perception of the impact of specific policies. A typical example of this approach was the State Department publication Iraq: From Fear to Freedom, which was produced in December 2002 and which sought to emphasize the human tragedy faced by the people of Iraq under the regime of Saddam Hussein. ${ }^{5}$

Beers is best known for the Shared Values Initiative (SVI), which was launched in October 2002 and cost \$15 million to produce. It was an integrated communication campaign involving public speeches abroad by US diplomats and American Muslims, internet sites and online chat rooms, the magazine Muslim Life in America, and newspaper advertisements. At the center of the campaign were five television commercials depicting American Muslims discussing their life in the United States. The commercials, or 'mini-documentaries' as the State Department called them, depicted religious tolerance in the United States and the positive experience of living there for ordinary citizens who were Muslim. The aim was to display a different view to the highly critical assumptions about US interests and values that were then circulating in the Middle East, not least that the USA was in principle hostile to Islam. The SVI series began broadcasting in Indonesia on 29 October 2002. However, hopes for a large-scale campaign were dented by the fact that several states either refused to air the commercials free of charge or, as in the case of Egypt, rejected them outright as no more than propaganda. As a result, the series was discontinued prematurely in December 2002. In June 2003, the US State Department launched an inquiry into the failure of SVI to improve America's image abroad, after an opinion poll conducted by the Pew Research Center for The People \& The Press found that negative views of the United States were on the rise in the Middle East. ${ }^{6}$ A top-level public diplomacy advisory group determined that while the concept was good, there was a greater need to examine why so many intended recipient countries rejected the campaign, which demonstrated that 'earlier incorporation of host-country expertise' was essential for a successful outcome (Advisory Group on Public Diplomacy for the Arab and Muslim World 2003: 72). 
Post-campaign polls conducted in Indonesia did indicate that the basic message had been taken in by the local population, and that it was a mistake to shut it down so soon (Fullerton and Kendrick 2006).

On 3 March 2003, shortly before the invasion of Iraq, Beers unexpectedly announced her resignation from the State Department. Although she cited unspecified 'health reasons,' it was clear from the previous 18 months not only that Beers' application of advertising principles was inadequate for the multi-faceted demands of US public diplomacy, but also that she knew, with the Iraq War looming, that the unpopularity of the USA around the world could only increase. But lessons were drawn from Beers' tenure. She was eventually replaced by Margaret Tutwiler, who assumed the Under Secretary position in October 2003. In contrast to Beers, Tutwiler was someone with a great deal of experience in US politics, both domestic and foreign, having served in top-level positions under both presidents Reagan and H.W. Bush before a stint in the private sector with the Cellular Telecommunications Industry Association (19952000). ${ }^{7}$ Before taking on the Under Secretary position Tutwiler was US ambassador to Morocco, where she encouraged all her embassy staff to engage with local communities, in particular, schools.

Tutwiler brought this firm belief in an interactive approach with her to the State Department, where she emphasized more active listening on the part of the U.S. government - including listening to its diplomats serving on the frontlines - and expanding the discussion of American values and policies to public venues outside of traditional elites in diplomacy and government. 'We only have to look at the activities of U.S. corporations overseas to see the value of being present and engaged in neighborhoods that we in government have for too long neglected. ${ }^{8}$ For Tutwiler, in stark contrast to Beers, the problems associated with 'branding' a country and selling its values abroad were complex. As she told the Senate Foreign Relations Committee during her confirmation hearing, "there is not one magic bullet, magic program or magic solution." Tutwiler concentrated on programs to build long-term relationships abroad, to this end securing an increase in funding for educational and youth exchanges and starting the Partnerships for Learning Undergraduate Studies Program (PLUS) which opened up the possibility for an American college education for younger people abroad who displayed academic excellence and leadership potential. ${ }^{10}$

Tutwiler, like Beers, was another victim of the collapse of US standing during the lead-up and follow-through of the Iraq War. It was no coincidence that Tutwiler's sudden announcement to leave the State Department for a job covering communications for the New York Stock Exchange in April 2004 coincided with the first brutal images of abused Iraqi prisoners at Abu Ghraib being released worldwide. ${ }^{11}$

\section{The Broadcasting Board of Governors (BBG)}

The Broadcasting Board of Governors (BBG) was created in 1999 as an independent body with the responsibility to oversee broadcasting operations such as the Voice of America (VoA), Radio Free Europe/Radio Liberty (RFE/RL), Radio Marti, and Radio Free Asia. In 2002 Congress granted an extra \$245 million for a rapid upgrade of broadcasting capability in the Near East. The first result of this was Radio Sawa (Radio Together), established in March 2002 as a 24-hour Arabic entertainment and current affairs radio station aimed at a youthful audience ( 65 per cent of the population in the region is below the age of 25). Radio Farda, broadcasting similarly in Farsi and 
aimed at Iran, was created jointly by the VoA and RFE/RL. Al-Hurra (The Free One), an Arabic satellite TV station, followed in early 2004. Both Sawa and Al-Hurra, which operated according to the Cold War models of Radio Free Europe, Radio Liberty, and Radio Free Asia (all of which are still operating) are funded by the BBG but run by the independent Middle East Broadcasting Networks Inc. A key individual behind both stations, and a member of the BBG itself, is Los Angeles media mogul Norman Pattiz, founder of the largest US radio conglomerate Westwood One. Al-Hurra was intended to directly challenge the prominence of Al-Jazeera, the satellite news channel based in Qatar, and the Saudi Arabian Al-Arabiya. Since 2006 Al-Hurra is also broadcast to Arabic-speaking audiences in Europe. However, their status as independent networks was undermined by their inability to air criticism of US policies, making them unable to build credibility by airing self-reflection and self-criticism. Once again, the urge to control the message and remove dissent has undermined a public diplomacy initiative. Both Sawa and Al-Hurra may gather audiences keen to sample American popular culture, but this is totally separate from being able to convince them that the US role in the Near East - particularly with regards to its relation with Israel - is beneficial for all. The overall negative impact of US foreign policy has undermined the credibility of its message, however it may be packaged. Both stations have also been funded at the expense of the Voice of America, a broadcaster that had precisely built up such credibility over several decades, and which lost its Arabic broadcasting capability as a result (Miles 2005: 382-8).

\section{The Defense Department and strategic influence}

On 20 September 2001, President Bush declared to a joint session of Congress that the war on terror against Al Qaeda and all terrorist organizations had begun. With military operations soon to begin in Afghanistan, it was clear that the Pentagon would occupy the driving role, including in the field of communications. Yet as one influential report stated in 2003 , the result is that:

the role the Defense Department plays in public diplomacy is neither broadly recognized nor well coordinated ... While the State Department is considered the lead agency ... we are concerned that the Defense Department, with resources that dwarf those of all other agencies of government, is not fully integrated into the public diplomacy architecture.

(Advisory Group on Public Diplomacy for the Arab and Muslim World 2003: 68)

The Pentagon's wish to control information and media affairs in support of the war on terror is based on its aim to secure 'strategic influence' and 'influence opinions, attitudes, and behaviour of foreign groups in ways that will promote US national objectives' (Gough 2003: 1). However, the methods to achieve this have crossed into explicit propaganda and psychological warfare operations. In October 2001, the Defense Department set up the Office of Strategic Influence (OSI), which had the task of conducting covert disinformation and deception operations, including planting false news items with disguised origins in the media abroad. In February 2002, the New York Times observed that it was OSI's intention to have these fabricated news reports picked up by US news media and distributed in the United States itself, as a means to bolster 


\section{Giles Scott-Smith and Martijn Mos}

domestic support for US actions overseas. Following the leak Rumsfeld was forced to shut down the organization, but the office's operations were effectively passed to another unit called the Information Operations Task Force (IOTF), and the goals did not change (Bamford 2005). In October 2003, the Defense Department issued the Information Operations Roadmap, which called for the formation of a strategic psychological operations unit and increased budgetary support for these activities. This was further backed up by the National Defense Strategy of March 2005, which included within the US military's dossier the intention to help 'change Muslim misperceptions of the United States and the West,' and to project the message that the war on terror 'is not a war against Islam' (The White House 2005).

A notable feature of the Pentagon's search for strategic influence since 2001 has been its use of the private sector. In October 2001, a contract worth $\$ 16$ million was awarded to John Rendon, leader of the public relations firm the Rendon Group and a wellknown practitioner of 'perception management.' Rendon had received several largescale contracts since the Gulf War in 1991, and had been closely involved with, first, the CIA and then the Pentagon in undermining Saddam Hussein's regime and running the dissident Iraqi National Congress of Ahmed Chalabi. In 2001, Rendon was given task of reversing the negative image of the United States abroad by tracking the global news cycle on a 24-hour basis and responding instantly to significant breaking news items. The Group effectively ran an Information War Room in the Pentagon's IOTF, and its principal target was the Qatar-based satellite channel Al-Jazeera, which the Pentagon considered its chief adversary in the war on terror's information campaign. Rendon's task stretched to working together with US allies (Saudi Arabia, Turkey, Egypt, Indonesia, Pakistan, and Uzbekistan) 'in developing and delivering specific messages to the local population, combatants, front-line states, the media and the international community' in support of US objectives (Bamford 2005). The implications of these kinds of activities for US public diplomacy as a whole are severe, since once again the need to sustain credibility over time has been replaced by the short-term demand to manipulate the news.

In November 2007, Robert Gates, the successor to Donald Rumsfeld as Secretary of Defense, gave a speech at Kansas State University during which he spoke of the need "to make the case for strengthening our capacity to use "soft" power and for better integrating it with "hard" power.' Declaring that the civilian tools of government needed a serious upgrade, Gates continued: 'Public relations was invented in the United States, yet we are miserable at communicating to the rest of the world what we are about as a society and a culture, about freedom and democracy, about our policies and out goals. ${ }^{12}$ To illustrate his point, he exclaimed that the State Department's foreign affairs budget of $\$ 36$ billion was less than what the Pentagon spent on health care. Meanwhile Gates created a new position, the Deputy Assistant Secretary of Defense for Support to Public Diplomacy. It is too early to say whether this means the Pentagon intends to cooperate more with the State Department, or if it signals a further entrenchment of its outreach into this field of activity.

\section{Transformational diplomacy}

That democracy promotion is a centerpiece of U.S. foreign policy under the presidency of George W. Bush was once more emphasized in his second Inaugural Address, where he insisted that it is 'the policy of the United States to seek and support the growth of 
democratic movements and institutions in every nation and culture with the ultimate goal of ending tyranny in our world.' The aim was to 'help others find their own voice,' a cause towards which the United States would offer every assistance. ${ }^{13}$

Building on this mandate, in January 2006, Secretary of State Condoleeza Rice outlined her vision for the future outlook of the State Department, termed Transformational Diplomacy, in an address at Georgetown University's School of Foreign Service: 'To work with our many partners around the world to build and sustain democratic, well-governed states that will respond to the needs of their people - and conduct themselves responsibly in the international system. ${ }^{14}$

Rice aimed to counter the criticism of the previous few years by situating the State Department as the central coordinator of US government information programs. To this end, it required revamping the Department 'to answer a new historic calling' around five themes. ${ }^{15}$ First, Global Repositioning required a shift of resources and personnel from traditional allies (Europe, Japan) to new ideological battlegrounds in Asia and the Near East (Indonesia, Malaysia, Egypt, India). Second, Regional Focus aimed to concentrate activities in Regional Public Diplomacy Centers that look beyond the limitations of nation-states and bilateral relations, the most important being the Regional Presence Center in Dubai which is directed at countering Iranian influence in the region. Third, Localization sought to spread the US diplomatic presence beyond capital cities by means of American Presence and Virtual Presence Posts. ${ }^{16}$ Fourth, Transformational Diplomacy required that 'diplomats must be diverse, well-rounded, agile, and able to carry out multiple tasks' working together with local communities. Lastly, it called for close Coordination with other agencies, in particular via the State Department's Office of Reconstruction and Stabilization, established in 2004 to ensure sufficient inter-departmental planning for post-conflict situations. With Iraq and Afghanistan in mind, it also called for a more prominent role for political advisors in coordination with military operations.

Transformational Diplomacy therefore attempts to position the State Department as a pivotal player combining diplomatic affairs, economic reconstruction and military operations within a broad strategy to promote democratic institutions abroad. Under this rubric, the second Bush administration took up a new worldview whereby nationbuilding, the strengthening of the rule of law and the creation of a strong and proactive civil society took on pre-eminence. As the Director of Policy Planning at the State Department and one of the leading architects behind the redesigned notion of diplomacy, Stephen Krasner, elucidated, 'transformational diplomacy is essentially about supporting changes within states, not relations among them' (CGD 2006). It was no longer the distribution of power between states, but the nature of their regimes that mattered most. As one commentator has noted, this signified 'a shift from classical realism to neo-conservatism' in the basic outlook of the State Department (Henrikson 2006: 34).

\section{Under Secretary of State Karen Hughes}

In September 2005, Rice gained a new Under Secretary to replace Tutwiler: Karen Hughes. Hughes had a long background working with Bush, having been his director of communications when he was Governor of Texas and staying in close contact thereafter before rejoining the President to assist in his re-election campaign in August 2004. Shortly after being appointed, Hughes spoke in Washington, DC, about her 


\section{Giles Scott-Smith and Martijn Mos}

intentions, and her initial statements - the need for a long-term strategy, the need to listen as much as to speak, and the need to 'foster a sense of common interests and common values between Americans and the people of different countries, cultures and faiths' - seemed to bode well for a much-needed new direction in US public diplomacy. ${ }^{17}$ The broad goals were as follows: Support the promotion of freedom and hope, isolate extremists, and strengthen shared values and common interests between Americans and the rest of the world. Hughes went on to talk of the four Es: Engage, Exchange, Educate and Empower. Engagement meant not only working with other partners in and outside the USA, but also to upgrade the State Department's media capacity with a Rapid Response Unit 'to monitor media and help us more aggressively respond to rumors, inaccuracies, and hate speech.' Exchange recognized that of all the forms of public diplomacy, exchange programs were consistently identified as the most effective means to build lasting cross-border understanding and relationships. Education focused on the need for Americans to learn other languages, and for others to learn English. Finally, Empowerment referred to the need to utilize to a greater extent the resources of US citizens and the private sector, since in many situations 'a government official may not be the most effective or the most credible voice.' ${ }^{18} \mathrm{~A}$ citizen ambassador program, particularly geared for American Muslims to go abroad as national advocates, was to be one result of this. All four of the E's were presented as forms of two-way communication - the United States would learn as much as it would tell.

In short, Hughes gave the strong impression that she was going to re-energize public diplomacy efforts, both institutionally (within the State Department as a whole) and procedurally (in terms of applying a New Public Diplomacy approach). But Hughes was also very much an administration insider, as demonstrated by her role in bodies such as the White House Iraq Group (or White House Information Group - WHIG), which was established in August 2002 under Karl Rove and had the task of convincing the US public of the need to neutralize the threat of Saddam Hussein's Iraq. Her determination to advocate US interests 'very aggressively' also did not bode well. Hughes did secure more funding for public diplomacy, with the State Department's allocation for these activities rising from \$519 million in 2004 to \$629 million in 2006 (GAO 2006: 5). Participants on State Department-sponsored exchange programs rose from 27,000 to 39,000 in the same period. ${ }^{19}$ But she never wavered in defending all aspects of US foreign policy, including the detention center at Guantánamo Bay. ${ }^{20} \mathrm{Her}$ approach did not work towards establishing dialogue with others but towards highlighting, once again with as much media coverage as possible, the merits of United States society and its policies, thereby undermining the two-way communication she seemed to promise when she arrived at the State Department. ${ }^{21}$

Hughes did work towards solving the lack of governmental coordination in public diplomacy, but this only further emphasized her wish to determine what the message was that was being sent out. In 2002, at the suggestion of Hughes, the Bush White House created the Office of Global Communications to coordinate strategic communications overseas in the aftermath of the Afghan campaign. This was supplemented in the same year by the Strategic Communication Policy Coordination Committee, run by the National Security Council and the State Department, with the aim of ensuring 'that all agencies work together to develop and disseminate America's message across the globe' (US Advisory Commission on Public Diplomacy 2004: 9). Yet this effort stalled, largely due to inter-agency inertia. In response to repeated criticisms that the 
State Department had failed to produce a clear strategy to both direct its own programs and to coordinate them with other departments and agencies (GAO 2006: 2), Hughes led the way in formulating a solution. Following on from Rice's announcement of Transformational Diplomacy, in April 2006, President Bush created the Policy Coordination Committee on Public Diplomacy and Strategic Communications, to be led by Hughes. In December 2006, this body issued the US National Strategy for Public Diplomacy and Strategic Communication, which stated that all public diplomacy activities should be carried out in support of national security objectives and fundamental values such as human rights and the 'struggle for freedom and democracy' (Policy Coordination Committee on Public Diplomacy and Strategic Communications 2006: 2). Faced with intense criticism abroad, the Bush administration therefore raised public diplomacy to being an issue of national security, in doing so undermining the possibility for open dialogue with others and dissenting opinion among its own officials. Announcing her resignation in late 2007, Hughes' said that she had succeeded in 'transforming public diplomacy and making it a national security priority central to everything we do in government. ${ }^{22}$ This was indeed an achievement, but not one that made use of the merits of two-way exchange, empowerment, and democratic legitimacy as outlined in the New Public Diplomacy. Hughes and Rendon were effectively the overt and covert sides to the same coin of controlling information and image in the interests of US national security. ${ }^{23}$

\section{USAID and democracy promotion}

The sharpened emphasis on democracy promotion within transformational diplomacy also implied a reorientation of the United States Agency for International Development (USAID). The logic of transformational diplomacy was transposed into a notion of transformational development. That the adjective of transformational implies a politicization of development aid became clear in the agency's budget and program overview for the 2007 fiscal year, which stated the intention to tie 'higher aid levels to countries that have made progress in building effective democracies, promoting economic freedom and investing in their own peoples. ${ }^{24}$

This means that progress in the field of development is not measured by traditional indicators such as literacy, nutrition and access to clean drinking water, but by 'political will and commitment to promote economic freedom, rule justly, and make sound investments in people. 25

In order to effectively carry out this strategy, the Secretary of State created a new position in 2006, namely that of Director of US Foreign Assistance (DFA). The position of DFA entails a rank equivalent to Deputy Secretary of State together with being USAID Administrator, 'ensuring that foreign assistance is used as effectively as possible to meet broad foreign policy objectives. ${ }^{26}$ As a result there has been a 'semi-fusion' of USAID with the State Department (Vaïsse 2007: 38). A typology has been crafted to distinguish between rebuilding countries that are engaging in post-conflict reconstruction; developing countries that are characterized by a low GDP but that do not meet the requirements for transformational development; and transforming countries that do display at least the prerequisite hallmarks of good governance (ibid.: 37). States that belong to this third category are eligible for funds from the Millennium Challenge Account (MCA). When announcing the plans for this initiative in Mexico in March 2002, George W. Bush remarked that 'greater contributions from developed nations 
must be linked to greater responsibility from developing nations,' requiring that the latter must meet performance indicators such as 'governing justly' (corruption, rule of law), 'investing in people' (immunization rates, primary education completion rates) and 'promoting economic freedom' (inflation, budget deficit, national trade policies). ${ }^{27}$ The MCA started functioning in 2004, and although overall US development assistance did increase, MCA effectively took funds away from USAID, and by setting highly political performance indicators many countries that are in dire need of foreign assistance are sidestepped. For example, the second Bush administration has invested, per capita, nearly fifty times as much on Egyptian citizens as it has on inhabitants from Bangladesh (ibid.: 34).

USAID could provide the basis for a New Public Diplomacy strategy that combines the talents and charitable energy of the private sector with a government-run development assistance program (Keilson 2006). Instead, it has had to contend with a continuing decline in funds (since the early 1990s), subordination to the newly-created MCA, and a wholesale politicization of its operations more in line with Strategic Public Diplomacy thinking. ${ }^{28}$

\section{Future prospects?}

Since 2001, the pattern in US public diplomacy has been clear. The language of New Public Diplomacy has been used, but Strategic Public Diplomacy has determined the goals and the methods. Established agencies - VoA, USAID - have been bypassed and underfunded while new creations - Radio Sawa, Al-Hurra, MCA - have been created and led by uncritical advocates of the Bush administrations. Transformational Diplomacy represented a significant move towards clarifying the State Department's mission and coordinating role, but increased resources to match the demands of this large-scale reformulation have not come with it. Meanwhile the emphasis remained on short-term image and information management, particularly in the autonomous (and often covert) operations of the Pentagon. As one source succinctly puts it, 'if it is true that public opinion in Arab and Muslim countries responds more to policies than to public diplomacy, it is clear that successful public diplomacy will not be able to change minds dramatically in the presence of strong opposition to policy' (Advisory Group on Public Diplomacy for the Arab and Muslim World 2003: 66).

The way ahead will be determined by the next administration under President Obama, but already significant statements have been made to try and map out what this might be. In November 2007, the independent Center for Strategic International Studies (CSIS) produced the report 'A Smarter, More Secure America,' which recognizes the need to bolster and maintain credible international organizations, respect international legal norms, and work with others towards solving common global problems (CSIS 2007). Equally significant was the Princeton Project on National Security that produced 'Forging a World of Liberty under Law' in September 2006, an extensive document that called for, among other things, a Concert of Democracies 'to institutionalise and ratify the "democratic peace" (Princeton Project for National Security 2006: 7). Both studies, which gathered together a bipartisan cross-section of some of the best US thinkers on foreign affairs, could lay the basis for frameworks of cooperation that are 'interest-based rather than threat-based' (ibid.: 6), and therefore open up opportunities for a genuine application of the New Public Diplomacy concept. But is it worth recalling that Obama's political philosopher of choice, Reinhold Niebuhr, argued 
from a Christian Realist position that the use of power had to be justified in a world where evil was omnipresent and inevitable. Such self-awareness and self-restraint will be necessary as Obama looks to forge a new foreign policy approach away from the crusade for democracy of the Bush years.

\section{Notes}

1 Murrow Center brochure. This and other definitions are available online at: http://www. publicdiplomacy.org/1.htm (accessed 29 May 2008).

2 Charlotte Beers (2001), 'Statement at Hearing: Public Diplomacy,' 10 October 2001, House Foreign Affairs Committee. Online. Available at:

3 Charlotte Beers (2002) 'Public Diplomacy after 9/11,' 18 December, National Press Club.

4 One example of third-party authenticity was the way in which Beers and the State Department in early 2003 persuaded Brookings Institution scholar Ken Pollack to undertake a series of digital video conferences and visits to countries such as France, Austria, Finland, Germany, Hungary, and South Africa to talk about the pros and cons of invading Iraq. Pollack's (2003) book The Threatening Storm had critically stated the case for invading Iraq, and his reasonable 'third voice' was considered a useful addition to the US government's efforts to sell the war.

5 The document is available online. Available at: http://usinfo.state.gov/products/pubs/iraq/ (accessed 30 May 2008).

6 The report is online. Available at: http://people-press.org/reports/display.php3?ReportID=185 (accessed 24 April 2008).

7 Tutwiler served under President Reagan as Deputy Assistant to the President for Political Affairs (1981-85) and Assistant Secretary for Public Affairs and Public Liaison with the Treasury (1985-89). She went on to serve as Assistant Secretary of State (March 1989-August 1992) and Special Adviser for Communications (August 1992-January 1993) for President George H.W. Bush. She was briefly, between January and June 2001, also President George W. Bush's Special Adviser for Communications.

8 Tutwiler (2004).

9 Tutwiler (2003).

10 PLUS is still running, although as of May 2008 there were only 175 students from Africa, the Middle East, and South Asia who were studying via PLUS in the United States. Online. Available at: http://exchanges.state.gov/education/p4l/ (accessed 29 May 2008).

11 Snow (2004).

12 Speech online, available at: http://www.defenselink.mil/speeches/speech.aspx?speechid+1199 (accessed 2 June 2008).

13 White House (2005b) 'President Sworn in for Second Term,' 20 January 2005, Press Release.

14 Rice (2006).

15 Department of State (2006) 'Transformational Diplomacy,' Fact Sheet, 18 January 2006.

16 In Korea, an internet community was created through the establishment of Café USA in which Korean citizens can debate in the Korean language with US officials on consular affairs, political and security issues, US-Korea relations and American history. See the US Embassy's website at http://seoul.usembassy.gov/cafeusa.html (accessed 2 June 2008).

17 Karen Hughes, speech at Loy Henderson Auditorium, 8 September 2005.

18 Ibid.

19 McKenna (2007).

20 'US Envoy Defends Guantanamo Conditions,' USA Today, 22 February 2006. Online. Available at: http://www.usatoday.com/news/world/2006-02-20-hughes-guantanamo_x.htm (accessed 2 June 2008).

21 Brown (2007).

22 'Key Bush Image Advisor to Leave,' BBC News, 31 October 2007. Online. Available at: http://news.bbc.co.uk/1/hi/world/americas/7071638.stm (accessed 2 June 2008).

23 In December 2007, President Bush nominated the chair of the BBG, American Enterprise Institute fellow James Glassman, as Hughes' successor, but it is unlikely that this will be confirmed before the 2008 elections. 


\section{Giles Scott-Smith and Martijn Mos}

24 Summary of FT 2007 Budget and Program Overview. Online. Available at: http://www.usaid. gov/policy/budget/cbj2007/summary.html (accessed 3 June 2008).

25 Ibid.

26 Director of US Foreign Assistance. Online. Available at: http://www.state.gov/f/ (accessed 3 June 2008).

27 The Millennium Challenge Account. Online. Available at: http://www.whitehouse.gov/infocus/ developingnations/millennium.html (accessed 3 June 2008)

28 USAID's allocation declined from $\$ 12.6$ million in 2004 to $\$ 9.1$ million in 2006. Summary of FT 2007 Budget and Program Overview. Online. Available at: http://www.usaid.gov/policy/ budget/cbj2007/summary.html (accessed 3 June 2008).

\section{References}

Advisory Group on Public Diplomacy for the Arab and Muslim World (2003) Changing Minds, Winning Peace, Washington, DC: US Government Printer.

Bamford, J. (2005) 'The Rendon Group,' Rolling Stone, 988. Online. Available at: HTTP: http:// www.rollingstone.com/politics/story/8798997/the_man_who_sold_the_war

Beers, C. (2001) 'Statement at Hearing: Public Diplomacy,' 10 October 2001, House Foreign Affairs Committee. Online. Available at: http://www.state.gov/r/us/5473.htm (accessed 30 May 2008).

(2002) 'Public Diplomacy after 9/11,' 18 December, National Press Club. Online. Available at: http://www.state.gov/r/us/16269.htm (accessed 24 April 2008).

Brown, J. (2007) 'Karen Hughes and Her "Diplomacy of Deeds", 9 April. Online. Available at: http://www.commondreams.org/archive/2007/04/09/411/ (accessed 24 April 2008).

Brown, R. (2004) 'Information Technology and the Transformation of Diplomacy,' Knowledge, Technology, \& Policy, 18: 1429.

CGD (Center for Global Development) (2006) 'Transformational Diplomacy.' Online. Available at: http://www.cgdev.org/doc/event\%20docs/Krasner\%20Transcript.pdf.

Council on Foreign Relations (2002) Public Diplomacy: A Strategy for Reform, Washington, DC: CFR Independent Task Force.

(2003) Finding America's Voice: A Strategy for Reinvigorating Public Diplomacy. Washington, DC: CFR Independent Task Force.

CRS (2005) Public Diplomacy: A Review of Past Recommendations, Congressional Research Service, September, Washington, DC: Library of Congress.

CSIS (Center for Strategic International Studies) (2007) 'A Smarter, More Secure America,' Commission on Smart Power. Online. Available at: http://www.csis.org/component/option, com_csis_pubs/task,view/id,4156/type,1/ (accessed 2 June 2008).

Cull, N.J. (2008) The Cold War and the United States Information Agency: American Propaganda and Public Diplomacy 1945-1989, Cambridge: Cambridge University Press.

Department of State (2006) 'Transformational Diplomacy,' Fact Sheet, 18 January. Online. Available at: http://www.state.gov/r/pa/prs/ps/2006/59339.htm (accessed 2 June 2008).

Dizard, W. (1961) The Strategy of Truth: The Story of the US Information Service, Washington, DC: Public Affairs Press.

(2004) Inventing Public Diplomacy: The Story of the US Information Agency, Boulder, CO: Lynne Rienner.

Fullerton, J. and Kendrick, A. (2006) Advertising's War on Terrorism: The Story of the US State Department's Shared Values Initiative, Spokane, WA: Marquette Books.

GAO (Government Accountability Office) (2006) 'US Public Diplomacy: State Department Efforts Lack Certain Communication Elements and Face Persistent Challenges,' Washington, DC: GAO.

Gough, S. (2003) 'The Evolution of Strategic Influence, USAWC Strategy Research Project.' Online. Available at: http:www.fas.org/irp/eprint/gough.pdf. 
Guehenno, J-M. (2000) The Decline of the Nation-State, Minneapolis: University of Minnesota Press.

Henrikson, A. (2006) What Can Public Diplomacy Achieve?, Discussion Papers in Diplomacy, Clingendael: Netherlands Institute of International Relations.

Hocking, J. (ed.) (1999) Foreign Ministries: Change and Adaptation, London: Macmillan.

- (2005) 'Rethinking the "New" Public Diplomacy,' in J. Melissen (ed.) The New Public Diplomacy: Soft Power in International Relations, London: Macmillan.

Hughes, K. (2005) Speech at Loy Henderson Auditorium, 8 September. Online. Available at: http://www.state.gov/secretary/rm/2005/52748.htm (accessed 29 May 2008).

Keilson, J. (2006) 'Opportunities for Public Diplomacy Programs in USAID and the Peace Corps,' in W. Kiehl (ed.) America's Dialogue with the World, Washington, DC: Public Diplomacy Council.

Leonard, M. (2002) Public Diplomacy, London: Foreign Policy Centre.

Manheim, J. (1994) Strategic Public Diplomacy and American Foreign Policy, New York: Oxford University Press.

McKenna, T. (2007) 'Hughes Tackles a Shaky Image'’ 23 July, PR Week. Online. Available at: http://www.prweek.com/us/news/article/671821/Hughes-tackles-shaky-image/ (accessed 24 July 2007).

Melissen, J. (ed.) (1999) Innovation in Diplomatic Practice, London: Macmillan.

_ (2005) 'The New Public Diplomacy: Between Theory and Practice,' in J. Melissen (ed.) The New Public Diplomacy: Soft Power in International Relations, London: Macmillan.

Miles, H. (2005) Al-Jazeera: How Arab TV News Changed the World, London: Abacus.

Nye, J. (2002) 'The Information Revolution and American Soft Power', Asia-Pacific Review, 9: 60-76.

Policy Coordination Committee on Public Diplomacy and Strategic Communications (2006) US National Strategy for Public Diplomacy and Strategic Communication, Washington, DC.

Pollack, K. (2003) The Threatening Storm, New York: Random House.

Princeton Project on National Security (2006) 'Forging a World of Liberty under Law,' G. John Ikenberry and Anne-Marie Slaughter (co-directors).

Public Diplomacy Council (2005) A Call for Action on Public Diplomacy, Washington, DC: author.

Rice, C. (2006) 'Transformational Diplomacy,' 18 January. Online. Available at: http://www.state. gov/secretary/rm/2006/59306.htm (accessed 2 June 2008).

Riordan, S. (2003) The New Diplomacy, Cambridge: Polity Press.

Snow, N. (2004) 'US Public Diplomacy: A Tale of Two who Jumped Ship at State' Foreign Policy in Focus, 27 May. Online. Available at: http://www.fpif.org/papers/0405taleoftwo_body. html\#_ftn1 (accessed 24 April 2008).

Tutwiler, M. (2003) 'Testimony before the Senate Foreign Relations Committee' 29 October. Online. Available at: http://www.state.gov/r/us/27372.htm (accessed 29 May 2008).

(2004) 'Public Diplomacy Activities and Programs,' 10 February, testimony before the House Committee on Government Reform, Subcommittee on National Security, Emerging Threats and International Relations. Online. Available at: http://www.state.gov/r/us/2004/ 29251.htm (accessed 30 May 2008).

US Advisory Commission on Public Diplomacy (2004) 'Report.' Online. Available at: http:// state.gov/document/organization/36625.pdf.

Vaïsse, J. (2007) 'Transformational Diplomacy,' Chaillot Papers, 103, EU Institute for Security Studies.

The White House (2005a) 'National Defense Strategy of the United States.' Online. Available at: http://www.globalsecurity.org/military/library/policy/dod/nds-usa_mar2005.htm.

— (2005b) 'President Sworn in for Second Term,' 20 January 2005, White House Press Release. Online. Available at: http://www.whitehouse.gov/news/releases/2005/01/20050120-21. html (accessed 2 June 2008).

Zwiebel, M. (2006) 'Why We Need to Reestablish USIA,' Military Review, 86: 26-35. 
240 Giles Scott-Smith and Martijn Mos

\section{Further reading}

Bogart, L. (1976) Premises for Propaganda: The United States Information Agency's Operating Assumptions in the Cold War, New York: Free Press.

Elder, R. (1968) The Information Machine: The United States Information Agency and American Foreign Policy, Syracuse, NY: Syracuse University Press.

Henderson, J. (1969) The United States Information Agency, Westport, CT: Praeger.

Lord, C. (2006) Losing Hearts and Minds? Public Diplomacy and Strategic Influence in the Age of Terror, Westport, CT: Praeger.

Snow, N. and Taylor, P. (eds) (2008) The Routledge Handbook of Public Diplomacy, London: Routledge.

Snyder, A. (1995) Warriors of Disinformation, New York: Arcade.

\section{Websites}

Pew Research Center's Global Attitudes Project: http://pewglobal.org/

Under Secretary of State for Public Diplomacy and Public Affairs: http://www.state.gov/r/

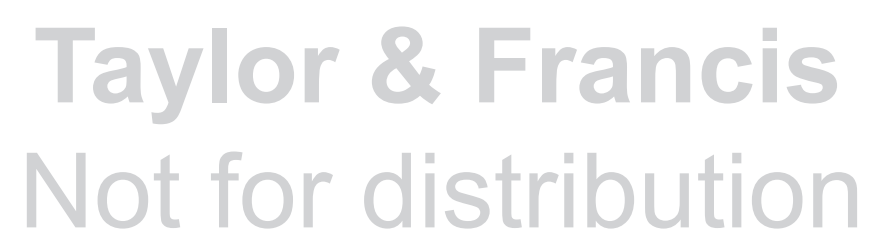

